\title{
Factors affecting the understanding and retention of the informed consent among participants at an antiretroviral clinical trial in a resource limited setting
}

\author{
Donald Salami ${ }^{1,2}$ \\ From 2nd Clinical Trials Methodology Conference: Methodology Matters \\ Edinburgh, UK. 18-19 November 2013
}

The misunderstanding of the informed consent has become a major area of concern particularly for participants of clinical trials in the developing regions/countries. This study assessed the understanding and retention of the informed consent among participants in an anti-retroviral clinical trial been conducted in Nigeria; and also the myriad of social, cultural \& economical factors affecting their understanding.

A structured questionnaire (QuIC) was administered to participants who signed consent to the lopinavir/ritonavir mono-therapy study, within the previous 12 months. The questionnaire assesses re-call of the basic elements of informed consent specified in federal regulations.

A total of 55 respondents completed the QuIC questionnaire. Majority age distribution was in the 30-49 age group (69.1\%), $10.9 \%$ had no education, $32.7 \%$ were not employed, $69.1 \%$ were females. $74.5 \%$ didn't know that the treatments and procedures in the clinical trial are not standard for their HIV management; $18.2 \%$ of respondents didn't know that the trial carried additional risks and discomfort in comparison to standard treatments; $38.2 \%$ were unsure if they were offered alternatives to participation; $32.7 \%$ were unsure as to who will pay for treatment if they were injured or become ill as a result of participation in this clinical trial. None of the demographics were significantly associated with knowledge scores. In the uni-variate model, none of the socioeconomic factors were independently associated with improved knowledge score.

${ }^{1}$ Maryland Global Initiatives Corporation, Jos Plateau State, Nigeria Full list of author information is available at the end of the article
Results suggest misunderstanding/deficiencies in certain important domain areas. This study reiterates the need for intensive studies in the area of therapeutic misconception as it has to do with HIV/AIDS preventive trials in developing countries.

\section{Authors' details}

${ }^{1}$ Maryland Global Initiatives Corporation, Jos Plateau State, Nigeria. 2University Of Liverpool(Laureate Online Education), Liverpool, UK.

Published: 29 November 2013

\section{doi:10.1186/1745-6215-14-S1-P89}

Cite this article as: Salami: Factors affecting the understanding and retention of the informed consent among participants at an antiretroviral clinical trial in a resource limited setting. Trials 201314 (Suppl 1):P89.

Submit your next manuscript to BioMed Central and take full advantage of:

- Convenient online submission

- Thorough peer review

- No space constraints or color figure charges

- Immediate publication on acceptance

- Inclusion in PubMed, CAS, Scopus and Google Scholar

- Research which is freely available for redistribution 